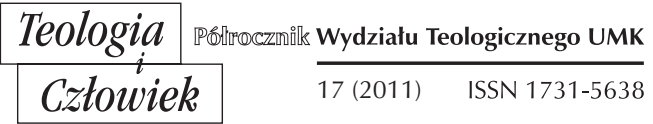

KS. DARIUSZ KWIATKOWSKI*

POZNAŃ-KALISZ

\title{
RZECZYWISTOŚĆ GRZECHU W CZYTANIACH BIBLIJNYCH OBRZĘDÓW SAKRAMENTU POKUTY
}

Sobór Watykański II docenił zbawczą moc słowa Bożego, jego walor kultyczny oraz ścisłą więź z liturgią eucharystyczną i dlatego postanowił „przywrócić czytania Pisma świętego dłuższe, bardziej urozmaicone i lepiej dobrane" ${ }^{\prime 1}$. W ten sposób uczestnicy każdej celebracji liturgicznej mają obficiej zastawiony stół słowa Bożego i szerzej otwarty skarbiec biblijny.

Proklamacja słowa Bożego ma szczególne znaczenie w liturgii pokutnej, w której pełni funkcję katechezy mistagogicznej. Z jednej strony ukazuje rzeczywistość grzechu i jego konsekwencje, a z drugiej strony mówi o przebaczeniu i pojednaniu. Poprzez słuchanie słowa Bożego dokonuje się proces ewangelizacji sumienia. Dobra nowina, którą słyszy penitent $\mathrm{w}$ liturgii sakramentu pokuty i pojednania prowadzi go do nawrócenia, czyli do powrotu do domu Ojca. W ten sposób słowo

* Ks. dr hab. Dariusz Kwiatkowski, kapłan diecezji kaliskiej. Obecnie pracuje w Wyższym Seminarium Duchownym w Kaliszu i jest adiunktem na Wydziale Teologicznym Uniwersytetu im. Adama Mickiewicza w Poznaniu. Jest redaktorem naczelnym „Kaliskich Studiów Teologicznych”.

${ }^{1}$ KL 35. 
Boże przygotowuje do właściwego przeżycia sakramentu pokuty i pojednania.

W szczególny sposób słowo Boże powinno być głoszone podczas nabożeństw pokutnych oraz $\mathrm{w}$ liturgii pojednania wielu penitentów $\mathrm{z}$ indywidualną spowiedzią. Wprowadzenie teologiczno-pastoralne do Obrzędów pojednania wielu penitentów z indywidualną spowiedzią i rozgrzeszeniem dostarcza wielu cennych uwag dotyczących głoszenia słowa Bożego podczas tej liturgii. W dokumencie czytamy między innymi: "Sakrament pokuty powinien zaczynać się od wysłuchania słowa Bożego, bo Bóg przez swoje słowo wzywa do pokuty i doprowadza do prawdziwego wewnętrznego nawrócenia"2. Znajdujemy tutaj także praktyczne i teologiczne kryteria doboru czytań do liturgii pokutnej. Mając na uwadze kryteria teologiczne, należy wybierać przede wszystkim takie czytania, w których głos Boży wzywa ludzi do nawrócenia i coraz większego upodobnienia się do Chrystusa. Ważne jest także, aby słowo Boże stawało przed oczami tajemnicę pojednania przez śmierć i zmartwychwstanie Chrystusa i przez dar Ducha Świętego. W końcu powinno ono przedstawiać sąd Boga o tym, co jest dobre i złe w życiu ludzi, aby $\mathrm{w}$ ten sposób oświecić i ułatwić zbadanie sumienia ${ }^{3}$.

Odnośnie ilości i układu liturgii słowa Bożego w Obrzędach pojednania wielu penitentów z indywidualną spowiedzią i rozgrzeszeniem, Wprowadzenie teologiczno-pastoralne mówi: „Można wybrać jedno lub kilka czytań. Jeżeli wybiera się kilka, miedzy nimi należy śpiewać psalm lub odpowiednią pieśń, albo zachować milczenie, aby ułatwić głębsze zrozumienie słowa Bożego i przyjęcie go w sercach. Jeśli jest tylko jedno czytanie, wypada wziąć je z Ewangelii"4. W dalszej części Rytuału znajduje się bardzo bogaty wybór czytań biblijnych, które mogą być wykorzystane w liturgii pokutnej. Oprócz podanego zestawu czytań jedna z rubryk Dodatku stwierdza: „Czytania tutaj podane zostały wybrane na użytek duszpasterzy i wiernych. W zależności od rodzaju i charakteru zgromadzenia wiernych można wybrać również inne czytania"

O wielkim bogactwie słowa Bożego w liturgii pokutnej świadczy liczba perykop biblijnych, która znalazła się w nowym Rytuale. Na li-

${ }^{2}$ Obrzędy Pokuty dostosowane do zwyczajów diecezji polskich, Księgarnia św. Jacka, Katowice 1981, 24 (=OP).

3 Tamże.

4 Tamże.

5 Tamże, s. 73. 
turgię Obrzędów pojednania wielu penitentów z indywidualną spowiedzią i rozgrzeszeniem można wybrać czytania spośród 108 propozycji zawartych w księdze. Czytania zostały wzięte zarówno ze Starego, jak i Nowego Testamentu: 33 perykopy ze ST, 17 Psalmów, 30 fragmentów z NT oraz 28 perykop wziętych z Ewangelii. Biblijne perykopy podejmują tematy ściśle powiązane $\mathrm{z}$ sakramentem pokuty i mówią o grzechu oraz jego konsekwencjach, pojednaniu, przebaczeniu oraz miłosierdziu.

Celem artykułu jest przedstawienie rzeczywistości grzechu i jego konsekwencji w życiu człowieka oraz w jego relacjach do Boga i bliźniego na podstawie wybranych czytań biblijnych wziętych z Lekcjonarz znajdującego się w "Obrzędach pokuty dostosowanych do diecezji polskich". We współczesnym świecie rozumienie grzechu znajduje się w poważnym kryzysie. Ma na to wpływ zmniejszająca się wrażliwość ludzkich sumień na Boga oraz przesadne pojęcie o wymiarach ludzkiej wolności, która prowadzi do zanegowania grzechu. Rzeczywistość grzechu jest rozumiana na różne sposoby. Precyzyjne określenie, czym jest grzech, zależy od światopoglądu, wyznawanej filozofii czy religii. Dla nas punktem odniesienia do zdefiniowania grzechu jest Pismo święte oraz nauczanie Kościoła. To drugie źródło bierze swój początek w pierwszym. Dlatego, aby dobrze zrozumieć istotę sakramentu pokuty i pojednania, trzeba najpierw odpowiedzieć na pytanie, czym jest grzech i zobaczyć jego konsekwencje.

\section{GRZECH W STARYM TESTAMENCIE}

Rzeczywistość grzechu ukazują następujące lektury ze Starego Testamentu: Rdz 3, 1-19; Rdz 4, 1-15; Rdz 18, 17-33; Wj 17, 1-7; Pwt 9, 7-19; Iz 43, 22-28; Is 59, 1-4.9-15; Jr 2, 1-13; Jr 7, 21-26. Psalmy: 12; 24; $30,1-6 ; 31 ; 35 ; 50 ; 94 ; 129 ; 142,1-11$.

Historia człowieka w Biblii rozpoczyna się od opisu stworzenia i obecności Adama i Ewy w raju. Pierwsi rodzice są figurą całej ludzkości. Dlatego też omawiając kwestię grzechu w życiu ludzkim należy sięgnąć do tekstów Starego Testamentu. Do omówienia interesującego nas zagadnienia zostaną wykorzystane następujące czytania z Księgi Rodzaju (Rdz 3, 1-9; Rdz 4, 1-15), a także z Księgi Powtórzonego Prawa (Pwt 30, 15-20) oraz z Księgi Wyjścia (Wj 17, 1-7).

Człowiek jest istotą, która ciągle poszukuje sensu własnego istnienia. W swych poszukiwaniach wielokrotnie spotyka Boga, który jest Miłością. Niestety, bardzo często człowiek w tę miłość wątpi i ją odrzuca. 
Tak rodzi się grzech. Dlatego też rozpoczynając rozważania o grzechu, należy zająć się kwestią zwątpienia, jako istotnego czynnika, który powoduje upadek człowieka.

\subsection{GRZECH JAKO ZWĄTPIENIE I ODRZUCENIE OJCOWSKIEJ MIŁOŚCI BOGA}

W tej części artykułu szczegółowej analizie zostaną poddane następujące czytania ze Starego Testamentu: z Księgi Rodzaju (Rdz 3, 1-19; Rdz 4,1-15) oraz z Księgi Powtórzonego Prawa (Pwt 30, 15-20). Czytania z Księgi Rodzaju ukazują narodziny grzechu oraz w jaki sposób dotykał on pierwszych ludzi i jakie wątpliwości w nich wzbudzał.

Bóg jest nieskończenie dobry i wszystkie Jego dzieła są dobre. Nikogo jednak nie omija doświadczenie cierpienia i zła obecnego w naturze ${ }^{6}$. Grzech jest obecny w historii człowieka i na próżno ktoś chciałby go nie zauważać lub nadawać inne nazwy tej mrocznej rzeczywistości. Usiłując zrozumieć grzech, trzeba najpierw uznać głęboką więź człowieka z Bogiem, gdyż poza tą relacją zło grzechu nie ujawnia się $\mathrm{w}$ swojej prawdziwej istocie jako odrzucenie Boga i przeciwstawienie się Jemu ${ }^{7}$. W każdą ludzką egzystencję wplecione jest zło nie tylko $\mathrm{w}$ wymiarze zewnętrznym, ale także zło wewnętrzne. Tym złem jest grzech. To swoiste mysterium iniquitatis, powoduje, że człowiek niejednokrotnie gubi się w życiu i odchodzi od Boga. Jednocześnie jednak istota ludzka dąży do swego Stwórcy, gdyż „niespokojne jest serce ludzkie dopóki nie spocznie w Bogu"8.

Potrzeba zatem sposobu, który umożliwi powrót do Boga. Okazuje się, że sam Stwórca dał człowiekowi taką możliwość. Jest nią sakrament pokuty i pojednania. Jednak żeby zrozumieć i odczuć potrzebę powrotu do Ojca, trzeba najpierw zrozumieć, czym jest grzech. Ogólnie można powiedzieć, że jest to zerwanie przez człowieka relacji z Bogiem. Dokonuje się ono poprzez konkretny akt nieposłuszeństwa wobec woli Bożej, objawionej najpierw przez Prawo, a potem przez Jezusa Chrystusa. Grzech wprowadza ludzi w stan wewnętrznego podzielenia, który wiedzie również do dysharmonii w związkach z drugim człowiekiem i ze światem9.

${ }^{6}$ Zob. KKK 385.

7 Tamże 386.

${ }^{8}$ Św. Augustyn, Wyznania, Znak, Kraków 2002, s. 25.

${ }^{9}$ Zob. G. Piana, Grzech, w: H. Witczyk (red.), Encyklopedia chrześcijaństwa, Wyd. Jedność, Kielce 2000, s. 227; S. Lyonnet, Grzech, w: X. L. Dufour (red.), Stownik teologii biblijnej, Pallottinum, Poznań 1994, s. 303 (=STB). 
Na początku trzeba postawić zasadnicze pytanie: skąd wziął się grzech? Jakie jest jego źródło? Te pytania stają się ważne, mając na uwadze, że na początku wszystko, co Bóg stworzył było dobre i piękne. Dotyczyło to także człowieka. Bóg jako dobry Ojciec przeznaczył dla ludzi wszelkie możliwe dobrodziejstwa. Jego wolą było także to, aby w zakresie poznania zachowana została pomiędzy Nim a ludźmi pewna granica. Określenie „poznanie dobra i zła” znacznie przekracza poznanie w sensie intelektualnym. Poznać dobro i zło oznaczało uzyskanie władzy nad wszystkimi rzeczami i tajemnicami. W ogrodzie rajskim człowiek odrzucił prostotę posłuszeństwa wobec Boga, chcąc poszerzyć swą naturę do miary Boga. Tym samym człowiek zapragnął postawić samego siebie we miejscu Boga ${ }^{10}$.

Teksty objawione jednoznacznie wskazują, że głównym powodem takiego stanu jest zwątpienie oraz nieufność człowieka w relacji do Boga. Do złego skłoniła go pokusa, która pochodziła od zewnątrz, czyli od kusiciela ${ }^{11}$. Tę nieufność w sercu człowieka zasiał szatan, na co wskazuje opis kuszenia pierwszych rodziców. W Obrzędach Pokuty umieszczony został fragment z Księgi Rodzaju 3, 1-19, gdzie ukazano narodziny grzechu i jego istotę ${ }^{12}$.

Szatan w sposób bardzo podstępny doprowadził Ewę do zwątpienia w Boga. Pokusa podpowiedziana przez niego, żeby postawić samego siebie na miejscu Boga, czyli żeby samemu decydować o tym, co dobre, a co złe i w ten sposób decydować o własnym losie była bardzo silna. $\mathrm{Na}$ tyle silna, że pierwsi ludzie odwrócili się od Boga i złamali prawo, które miało ich ochraniać przed śmiercią. Ich działanie wynikało ze zwątpienia i odrzucenia Boga jako kochającego Ojca.

Szatan przedstawiony w obrazie węża nie od razu zachęcał do grzechu. Najpierw pochlebiał wolności i niezależności człowieka, którego Bóg skrępował swoim przykazaniem. Fałszywie je wyolbrzymiał, dziwiąc się przy tym, że dobry Bóg zakazał ludziom spożywania owocu ze wszystkich drzew rajskich ${ }^{13}$. Pytania szatana było bardzo podchwytliwe i podstępne: "Czy to prawda, że Bóg powiedział: Nie jedzcie owoców ze wszystkich drzew tego ogrodu?" (Rdz 3, 1). Niewiasta weszła w dialog

${ }^{10}$ Por. G. von Rad, Teologia Starego Testamentu, Instytut wydawniczy „Pax”, Warszawa 1980, s.129-130.

${ }^{11}$ Por. S. Łach, Ksiega Rodzaju, Wstęp - przektad z oryginatu, komentarz t. I, cz. 1, Pallottinum, Poznań 1962, s. 213.

12 OP 95.

${ }^{13}$ Por. S. Łach, Ksiega Rodzaju, s. 215. 
z wężem i próbowała mu wyjaśnić zakaz Boży: „Owoce z drzew tego ogrodu jeść możemy, tylko o owocach z drzewa, które jest w środku ogrodu, Bóg powiedział: Nie wolno wam jeść z niego, a nawet go dotykać, abyście nie pomarli" (Rdz 3, 2). Wtedy szatan oskarżył Boga o brak prawdomówności i dobroci względem ludzi: „Na pewno nie umrzecie! Ale wie Bóg, że gdy spożyjecie owoc z tego drzewa, otworzą się wam oczy, i tak jak Bóg będziecie znali dobro i zło" ( $\mathrm{Rdz} 3,4-5)$.

Kłamliwa pokusa szatana obudziła w kobiecie pragnienie uniezależnienia się od Boga. Zwiedziona niewiasta uległa myśleniu szatana i stała się uwodzicielką mężczyzny, który był razem z nią. Kobieta zerwała owoc z drzewa poznania dobra i zła, skosztowała go i dała swemu mężowi, który był z nią, a on zjadł. A wtedy otworzyły im obojgu oczy i poznali, że są nadzy (por. Rdz. 3, 7). Chęć postawienia samych siebie w miejscu Boga Stwórcy przywiodła pierwszych ludzi do przekroczenia Bożego zakazu. Prarodzice zwątpili w Bożą miłość i zapragnęli żyć według zasad ustalanych przez samych siebie. Było to spowodowane pokusą diabła ${ }^{14}$.

Należy jednak zobaczyć, że szatańska pokusa okazała się pułapką. Miało być szczęście, zadowolenie, wielkość, spełnienie się, a tymczasem pojawił się strach, egoizm, ucieczka. Pierwsi rodzice ukryli się przed Bogiem, kiedy usłyszeli, że On nadchodzi. Najpierw odkryli, że są nadzy. W Piśmie Świętym nagość oznacza słabość, kruchość i przemijalność ludzkiego życia. Potem, gdy Bóg zaczął z nimi rozmawiać, zaczęli się nawzajem obwiniać o popełniony czyn. Wygnanie z rajskiego ogrodu jest obrazem życia, w którym człowiek żyje w oddaleniu od Boga, swojego Ojca i Stwórcy. Każdy grzech odwraca człowieka od Boga i skazuje na życie w cierpieniu, lęku i samotności ${ }^{15}$.

Lęk i wstyd to dwa stygmaty, które wycisnął grzech na duszy pierwszych ludzi. Próbowali ukryć się przed Bogiem, świadomi swej grzeszności i napełnieni lękiem kary. Adam i Ewa skryli się w zaroślach, co faktycznie oznacza oddalenie się od źródła swego życia i odejście od Boga. Grzech stanowi nie tylko akt zerwania związku miłości z Bogiem, lecz jest również odmową kochania innych ludzi ${ }^{16}$. Konsekwencją

${ }^{14}$ Por. S. Rinaudo, Il Lezionario del Rito della Penitenta, w: AA.VV., La Penitenza. Studi biblici, teologici e pastorali il nuovo Rito della Riconciliazione, Elle Di Ci, Leumann (Torino) 1989, s. 225.

${ }^{15}$ Por. P. Góralczyk, Wyzwolenie człowieka z grzechu, „Communio” 5 (1990) 6.

${ }^{16}$ Por. S. Łach, Ksiega Rodzaju, s. 216. 
zwątpienia w miłość Boga jest również zwątpienie w miłość drugiego człowieka. Grzech miłość skaził egoizmem.

Grzech domagał się kary. Bóg wymierzył ją najpierw wężowi: „Bądź przeklęty wśród wszystkich zwierząt domowych i polnych [...] Wprowadzam nieprzyjaźń między ciebie a niewiastę, pomiędzy potomstwo twoje a potomstwo jej: ono zmiażdży ci głowę, a ty zmiażdżysz mu piętę" (Rdz 3, 14-15). Te słowa można nazwać pierwszym opisem walki, która odtąd będzie się toczyć między dobrem i złem, między człowiekiem i szatanem. Stanowią one zapowiedź zamierzonej przez Boga walki, która nigdy nie ustanie na świecie ${ }^{17}$.

Wyrok Boży nie przekreśla całkowicie człowieka, ale wprost przeciwnie, głosi równocześnie dobrą nowinę dla ludzkości. W tym tekście zwanym Protoewangelią znajdujemy zapowiedź zwycięstwa nad grzechem i szatanem. Bóg wyraźnie obiecuje, że szatan, zostanie zwyciężony, a jego głowę zniszczy potomstwo Ewy. Nie stanie się to od razu i wąż jeszcze wielokrotnie będzie ranić piętę potomstwa niewiasty. Niewiastą, którą zapowiada Protoewangelia, będzie Maryja, która odpowie Bogu całkowitym posłuszeństwem. Bóg po upadku pierwszych ludzi nie zerwał z nimi więzi i nadal im pomagał, ale ludzie we wszystkim, cokolwiek robią pozostaną pod władzą grzechu i jego skutków, z których najstraszliwsza jest śmierć. Sytuacja zmieni się dopiero po dziele zbawienia dokonanym przez Chrystusa ${ }^{18}$.

Kara za nieposłuszeństwo dotknęła również niewiastę i mężczyznę. Nie zostali oni przeklęci przez Boga, ale otrzymali zasłużoną karę: „W bólu będziesz rodziła dzieci, ku twemu mężowi będziesz kierowała swe pragnienia, on zaś będzie panował nad tobą" $(\operatorname{Rdz} 3,16)$. Niewiasta pierwotnie miała być pomocą dla męża. Tak było w stwórczych zamiarach Boga. Po grzechu stała się jemu uległa. Relacje miłości i przyjaźni zostały wyraźnie zniekształcone. Mężczyźnie Bóg zapowiedział podwójną karę: ciężką pracę dla zdobycia środków utrzymania oraz śmierć: „W pocie więc oblicza twego będziesz musiał zdobywać pożywienie, póki nie wrócisz do ziemi, z której zostałeś wzięty; bo prochem jesteś i w proch się obrócisz!" $(\operatorname{Rdz} 3,19)^{19}$.

${ }^{17}$ Por. tamże, s. 218.

${ }^{18}$ Por. L. Boadt, Księga Rodzaju, w: W. R. Farmer (red.), Międzynarodowy komentarz do Pisma Świętego, Verbinum, Warszawa 2000, s. 280.

${ }^{19}$ Por. S. Łach, Księga Rodzaju, s. 220. 
Inicjatywa grzechu wyszła od człowieka, ponieważ to on wzgardził Bogiem i uciekł od Niego. Po wypędzeniu z raju zrozumiał, że ostrzeżenie Boga nie było kłamstwem. Człowiek przestał mieć dostęp do drzewa życia, gdyż został wypędzony z raju (zob. Rdz 3, 22). Pozostała mu już tylko śmierć $\mathrm{i}$ to śmierć całkowita ${ }^{20}$.

Konsekwencje grzechu rozumianego jako zwątpienie i odrzucenie Boga ukazuje także Księga Powtórzonego Prawa: "Ja dziś nakazuję ci miłować twego Pana i Boga i chodzić Jego drogami, pełniąc Jego polecenia, prawa i nakazy, abyś żył i mnożył się, a twój Pan Bóg będzie ci błogosławił. Ale jeśli swe serce odwrócisz, nie usłuchasz, zbłądzisz i będziesz oddawał pokłon obcym bogom, służąc im, oświadczam wam dzisiaj, że na pewno zginiecie" (Pwt 30, 16-18). W tych słowach mieści się zarówno obietnica błogosławieństwa za wierność Prawu oraz przestroga przekleństwa za niewierność ${ }^{21}$.

Potwierdzeniem tego, że obietnice i groźby zostaną spełnione jest apel do świadków, na których wezwane są niebo i ziemia: „Biorę dziś przeciwko wam na świadków niebo i ziemię, kładę przed wami życie i śmierć, błogosławieństwo i przekleństwo. Wybierajcie więc życie, abyście żyli wy wasze potomstwo, miłując Boga swego, Pana, słuchając Jego głosu" (Pwt 30, 19-20). Do Izraela posiadającego znajomość prawa i jego sankcji, należy wybór między życiem i dobrem, śmiercią i złem.

Stary Testament $\mathrm{w}$ grzechu widzi odwrócenie się od Boga, spowodowane zwątpieniem w Jego przyjaźń. Księgi Starego Przymierza opisując grzech pojedynczego człowieka używają następujących terminów: „uchybienie normie Bożej”, „wystąpienie bądź bunt przeciw Bogu”, „zejście z drogi Bożej”. Oznacza to, że grzech nie spada na człowieka niczym jakaś siła wyższa, ale jest on jego wyborem ${ }^{22}$. Poprzez grzech człowiek utracił lekkomyślnie życie $\mathrm{w}$ rajskim ogrodzie charakteryzujące się harmonią i jednością w relacjach do Boga, do drugiego człowieka i siebie samego. Tym samym skazał siebie samego na życie $\mathrm{w}$ trudzie, niepewności, w walce ze złem, przeciwnościami i w końcu na śmierć23.

\footnotetext{
s. 226.

${ }^{21}$ Por. S. Łach, Pismo Święte Starego Testamentu, Księga Powtórzonego Prawa, t. II, cz.3, Pallottinum, Poznań 1971, s. 266.

${ }^{22}$ Por. S. Ormanty, Biblijny zarys anatomii grzechu $i$ winy, "Kaliskie Studia Teologiczne" 3 (2004) 306.

${ }^{23}$ Por. G. von Rad, Teologia Starego Testamentu, s. 130.
}

${ }^{20}$ S. Lyonnet, Grzech, s. 304; S. Rinaudo, Il Lezionario del Rito della Penitenta, 
Zwątpienie w Bożą miłość, które szatan zasiał w sercu człowieka na początku historii zbawienia z czasem ewoluuje i niestety coraz bardziej pogłębia się. Przechodzi ono na kolejne pokolenia i na synów Adama. Obrzędy Pokuty zawierają perykopę wziętą z Księgi Rodzaju, która ukazuje zabójstwo Abla. Bracia Kain i Abel składali ofiary Bogu. Tekst nie wyjaśnia, dlaczego Bóg różnie się odniósł do ofiar obu braci. Mamy jedynie proste stwierdzenie faktu: „Pan wejrzał na Abla i na jego ofiarę; na Kaina zaś i na jego ofiarę nie chciał patrzeć. Smuciło to Kaina bardzo i chodził z ponurą twarzą. (Rdz 4,5).

Bóg nie przerywa jednak dialogu z Kainem i mówi do niego: „Przecież gdybyś postępował dobrze, miałbyś twarz pogodną; jeżeli zaś nie będziesz dobrze postępował, grzech waruje u wrót i łasi się do ciebie, a przecież ty masz nad nim panować" (Rdz 4, 7). Ojcowska przestroga przed grzechem, a zarazem pouczenie o drodze do dobrego, nie dotarly do Kaina. Autor natchniony podkreśla, że Kaina opanowały gniew i zazdrość. Te złe emocje doprowadziły w konsekwencji do bratobójstwa, zasługującego na karę Bożąa ${ }^{24}$. Katechizm Kościoła Katolickiego przypomniał, że: „Pismo Święte w opisie zabójstwa Abla przez jego brata Kaina ukazuje od początku historii ludzkości obecność w człowieku gniewu i pożądliwości, skutków grzechu pierworodnego. Człowiek stał się nieprzyjacielem swego bliźniego"25.

Kain próbował ukryć przed Bogiem prawdę o zbrodni: „Nie wiem. Czyż jestem stróżem brata mego?" (Rdz 4, 9). Jednak Boga nie mógł oszukać i zaraz usłyszał wyrok za swój zbrodniczy czyn: „Bądź więc przeklęty na tej roli, która rozwarła swą paszczę, aby wchłonąć krew brata twego, przelaną przez ciebie. Gdy rolę tę będziesz uprawiał, nie da ci już ona więcej plonu. Tułaczem i zbiegiem będziesz na ziemi" (Rdz 4, 11-12). Tekst pokazuje, że Bóg wyraża troskę o zamordowanego brata, a cyniczna odpowiedź Kaina zostaje odrzucona. Bóg jednoznacznie i pod groźbą klątwy chce, abyśmy byli stróżami naszych braci ${ }^{26}$.

Kain mimo niewinnie przelanej krwi braterskiej nie został ukarany śmiercią, a każdy, kto próbowałby zabić go, poniesie za to siedmioraką karę. Kain nie zrozumiał, że Bóg nie chciał go ukarać śmiercią. On zwątpił w Jego ojcowską miłość. Człowiek, wątpiąc w Boga, wątpi w drugiego człowieka i ostatecznie także w samego siebie. Ta wątpliwość powoduje,

\footnotetext{
${ }^{24}$ Por. L. Boadt, Ksiega Rodzaju, s. 281.

${ }^{25}$ KKK 2259.

${ }^{26}$ Por. L. Boadt, Księga Rodzaju, s. 281.
} 
że istota ludzka zaczyna żyć w kłamstwie, w nieprawdzie dotyczącej całej swojej egzystencji ${ }^{27}$.

Człowiek niemal od początku swego istnienia dążył do uniezależnienia się od Stwórcy. Pragnął postawić samego siebie w miejscu Boga i stać się $w$ ten sposób niezależnym i wszechwiedzącym. Przez grzech, którego istotą było zwątpienie w ojcowską miłość Boga, utracił przyjaźń z Bogiem i nieśmiertelność, dzięki której był podobny do swego Stwórcy. Grzech jest rzeczywistością, która niszczy człowieka od wewnątrz: niszczy jego wewnętrzną strukturę poprzez wprowadzenie nieufności wobec samego siebie, innego człowieka i samego Boga. To sprawia, iż człowiek staje się nieszczęśliwy. To nieszczęście powoduje, że istota ludzka, obwiniając o taki stan Boga, postanawia bardziej lub mniej świadomie wypowiedzieć $\mathrm{Mu}$ nieposłuszeństwo ${ }^{28}$.

\subsection{GRZECH JAKO NIEPOSŁUSZEŃSTWO}

Prawda o człowieku jest niezwykle złożona i składa się na nią także rzeczywistość grzechu. Bóg stworzył człowieka na swój obraz i swoje podobieństwo. Człowiek został stworzony do życia w przyjaźni i jedności z Bogiem. Będąc stworzeniem posiadającym ducha, człowiek mógł przeżywać tę przyjaźń tylko przez dobrowolne poddanie się Bogu i całkowite zawierzenie Jego miłości, wyrażonej także w zakazie spożywania owoców z drzewa poznania dobra i zła. Nakaz ten symbolicznie przywołuje nieprzekraczalną granicę, którą człowiek powinien w sposób wolny uznać i szanowaće ${ }^{29}$. Jednak człowiek kuszony przez szatana pozwolił, aby zamarło w nim zaufanie do Stwórcy. Nadużył swojej wolności i okazał nieposłuszeństwo Bożemu przykazaniu. Popełnił grzech, którego istotą stało się nieposłuszeństwo wobec Boga. Od tamtego wydarzenia każdy grzech jest nieposłuszeństwem względem Boga i Jego słowa. W Księdze Rodzaju bardzo wyraźnie przedstawione jest nieposłuszeństwo względem Boga, którego dopuścili się pierwsi rodzice. Była to ich świadoma decyzja, po uległości podszeptom szatana. Nieposłuszeństwo ukazane zostało jako sprzeciw woli Bożeje.

${ }^{27}$ Por. P. Henrici, Grzech jako nieprawda, "Communio" 5 (1990), s. 22-32.

${ }^{28}$ Por. G. von Rad, Teologia Starego Testamentu, s. 130-132.

${ }^{29}$ Por. KKK 396.

${ }^{30}$ Por. tamże 397. 
Pismo Święte pokazuje dramatyczne konsekwencje pierwszego nieposłuszeństwa. Adam i Ewa utworzyli fałszywy obraz Boga, jako zazdrosnego o swoje przywileje. Szatan zasiał niepokój w ludzkich sercach mówiąc: „Ale wie Bóg, że gdy spożyjecie owoc z tego drzewa, otworzą się wam oczy, i tak jak Bóg będziecie znali dobro i zło" (Rdz 3, 5). Ludzie uwierzyli szatanowi i w jednej chwili ustalona harmonia, w której żyli została zniszczona oraz zostało zerwane panowanie duchowych władz duszy nad ciałem. Nieposłuszeństwo zburzyło najpierw relację przyjaźni do Boga. Konsekwencje zerwanych relacji były straszne: „A wtedy otworzyły się im obojgu oczy i poznali, że są nadzy; spletli więc gałązki figowe i zrobili sobie przepaski" (Rdz 3, 7). Człowiek poznał prawdę o swojej słabości, kruchości i przemijalności ${ }^{31}$.

Grzech, którego istotą było zwątpienie w miłość Boga i nieposłuszeństwo względem Boga, zniszczył także pierwotną jedność mężczyzny i kobiety: „Któż ci powiedział, że jesteś nagi? Czy może zjadłeś z drzewa, z którego ci zakazałem jeść? [...] Niewiasta dała mi owoc z tego drzewa i zjadłem" (Rdz 3, 11-13). Pierwsi rodzice dzięki miłości Boga zostali stworzeni w stanie doskonałej szczęśliwości. Oni posiadali przywilej nieśmiertelności, wielkiej wiedzy, oraz doskonałą nieskazitelność. Ich szczęście z potrójnym darem wyrażało się $\mathrm{w}$ życiu w bliskiej przyjaźni z Bogiem. Trwałość ich szczęścia była uzależniona od posłuszeństwa Bożemu przykazaniu ${ }^{32}$. Odrzucenie Boga przyniosło egoizm i skażenie miłości między ludźmi. Po popełnieniu grzechu relacje pomiędzy pierwszymi ludźmi będą naznaczone pożądaniem i chęcią panowania: „Obarczę cię niezmiernie wielkim trudem twej brzemienności. Ku twemu mężowi będziesz kierowała swe pragnienia, on zaś będzie panował nad tobą" (Rdz 3 , 16). Grzech doprowadził do skłócenia ludzi między sobą już w raju. Adam po popełnieniu grzechu nie chciał mieć nic wspólnego z kobietą i oskarżył ją przed Bogiem, obarczając ją całą winą za nieposłuszeństwo i zerwanie owocu z drzewa poznania dobra i zła ${ }^{33}$.

Konsekwencją grzechu było całkowite odwrócenie pierwotnego i właściwego porządku. Grzech stał się nieposłuszeństwem Bogu. Przekroczenie przykazania nie tyle jest wykroczeniem przeciw prawu, czy wyrządzeniem szkody, ile raczej niewłaściwym i kłamliwym ustawieniem własnej woli, która wymyka się spod autorytetu Boga. W Starym

\footnotetext{
${ }^{31}$ Por. S. Lyonnet, Grzech, s. 304-305.

32 Por. S. Łach, Ksiega Rodzaju, s. 222.

${ }^{33}$ Por. S. Lyonnet, Grzech, s. 304.
} 
Testamencie grzech rozumiany był jako konflikt pomiędzy wolą Boga a wolą człowieka. Grzech stanowi niewątpliwie zanegowanie miłości Bożej, poprzez zamknięcie się człowieka w samym sobie, $\mathrm{w}$ pewnego rodzaju samowystarczalności. Odrzucając miłość Bożą, człowiek stawia tym samym siebie na miejscu Boga i absolutyzuje swoje , ,ja" ${ }^{\prime \prime 34}$. Ważne jest tutaj spostrzeżenie, że w Starym Testamencie grzech był jednocześnie karą samą w sobie. To nie Bóg karze, ale człowiek karze samego siebie. To grzech jako zło wywołuje śmierć, malejący czas trwania życia kolejnych patriarchów, osłabienie więzi międzyludzkich. Od chwili upadku pierwszych ludzi, grzech rozrastał się i objął nie tylko jednostkę, ale całą ludzką społeczność35.

Nieposłuszeństwo wobec Boga okazywał również naród wybrany, który dzięki łasce Boga został wyzwolony z niewoli egipskiej. Bóg wybrał i powołał naród izraelski do życia w szczególnej przyjaźni i bliskości z Nim. Oczekiwał, aby Izrael był Mu wierny i przyjmował to wszystko, co objawił dla jego dobra. Wędrówka przez pustynię do ziemi obiecanej dostarcza wielu przykładów buntu i nieposłuszeństwa Izraelitów względem Boga. Rzeczywistości te ukazuje czytanie wzięte z Księgi Wyjścia, które mówi o narzekaniu narodu wybranego na Boga, kiedy zabrakło im wody (Wj 17, 1-7). Lud rozgoryczony brakiem wody, robił Mojżeszowi wymówki: „I kłócił się lud z Mojżeszem mówiąc: 'Daj nam wody do picia'. Mojżesz odpowiedział im: 'Czemu kłócicie się ze mną? I czemu kusicie Pana?" (Wj 17, 2). Izraelici, mimo że nieustannie doświadczali bliskości i mocy Boga, wciąż narzekali i wystawiali Boga na próbę. Poza tym, wcześniejsze cuda przyzwyczaiły lud do tego, że mógł on liczyć na wstawiennictwo Mojżesza. Naród nie był posłuszny woli Bożej i nie potrafił uwierzyć w zbawcze działanie Boga: „Ale lud pragnął tam wody i dlatego szemrał przeciw Mojżeszowi i mówił: 'Czy po to wyprowadziłeś nas z Egiptu, aby nas, nasze dzieci i nasze bydło wydać na śmierć z pragnienia?'" (Wj 17, 3). Tymi słowami Izraelici zakwestionowali sens uwolnienia i wyjścia z niewoli egipskiej. Oznacza to odrzucenie zbawczego planu Boga i nieposłuszeństwo względem Niego ${ }^{36}$.

Te utarczki świadczą o tym, że Izrael zapragnął żyć jakby według swojego własnego planu, całkowicie pomijając wolę Bożą. Oni wprost

${ }^{34}$ P. Góralczyk, Wyzwolenie człowieka z grzechu, s. 5.

${ }^{35}$ Por. KKK 400-401.

${ }^{36}$ Por. J. F. Craghan, Księga Wyjścia, w: W. R. Farmer (red.), Międzynarodowy komentarz do Pisma Świętego, s. 340. 
odrzucali plany Boga i przez to dopuszczali się nieposłuszeństwa. Mojżesz wstawił się za Izraelitami i Bóg kazał mu laską uderzyć w skałę na Horebie (zob. Wj 17, 7). Skała jest tutaj symbolem twardego serca Izraelitów. Bóg ma moc z tego nieposłusznego serca wyprowadzić ożywiającą wodę. Pojawia się tu kwestia grzechu o wymiarze społecznym. Powszechnie wiadomo, że człowiek nie podejmuje decyzji w próżni, lecz w kontekście otaczającej go rzeczywistości. Każde zło popełnione przez człowieka w jakiś sposób promieniuje na innych ${ }^{37}$.

Zwątpienie i odrzucenie Boga jako kochającego Ojca oraz nieposłuszeństwo względem Boga stanowią istotę grzechu w Starym Testamencie. Można stwierdzić, że grzech jest ogromną tragedią człowieka, który poprzez własną nieufność wobec Boga odwraca się od Niego i ostatecznie staje się Jemu nieposłuszny. Konsekwencją grzechu jest zerwanie relacji przyjaźni człowieka z Bogiem, drugim człowiekiem i sobą samym. Trwając w grzechu człowiek skazuje się na samotność i śmierć.

\section{GRZECH W NOWYM TESTAMENCIE}

Czytając Ewangelię z łatwością odkrywamy swego rodzaju paradoks. Dobra nowina głoszona przez Jezusa przynosi bardzo wyraźną świadomość doświadczenia grzechu. W spotkaniu z Jezusem i głoszonym przez Niego słowem człowiek w bardzo ostry sposób widzi własny grzech. Tak było w przypadku choćby celnika Mateusza (Mt 9, 9-13), Marii Magdaleny (Łk 7, 36-49) czy św. Piotra (Łk 5, 4-11). Jednak trzeba zaraz dodać, że ta świadomość grzechu nie niszczy człowieka, ale przeciwnie, prowadzi go do nawrócenia. Stało się możliwe dzięki temu, że nauczanie Jezusa ściśle związane jest z odpuszczeniem grzechów. Cała zbawcza misja Jezusa skierowana jest ku grzesznikom. On sam powie, że przyszedł szukać i ocalić to, co zginęło oraz że lekarza nie potrzebują zdrowi, ale ci, którzy się źle mają ${ }^{38}$.

Teksty Nowego Testamentu najczęściej ukazują rzeczywistość grzechu w połączeniu ze zbawczym działaniem Jezusa Chrystusa. On przyszedł na ziemię, ponieważ chciał ocalić to, co zginęło i dlatego od początku swojej publicznej działalności „poszukuje” grzeszników, aby przebaczyć ich grzechy i wyzwolić z niewoli zła. Faryzeuszom zgor-

${ }^{37}$ Zob. P. Góralczyk, Społeczny wymiar grzechu, "Communio" 5 (1984), s. 39-41.

${ }^{38}$ Por. D. Kwiatkowski, Grzech w Nowym Testamencie, „Opiekun” 246 (2007) 10. 
szonym faktem przebywania z grzesznikami, Jezus odpowiadał: „Nie potrzebują lekarza zdrowi, lecz ci, którzy się źle mają. Nie przyszedłem powoływać sprawiedliwych, ale grzeszników" (Mt 9, 12-13). Ewangelie dostarczają nam wielu przykładów odpuszczenia grzechów ludziom, którzy spotykali Jezusa. Wystarczy wspomnieć choćby człowieka sparaliżowanego (Mt 9, 1-8), powołanie Mateusza (Mt 9, 9-13), kobietę grzeszną, która przyszła do domu faryzeusza Szymona (Łk 7, 36-49), kobietę z Samarii (J 4, 1-42), kobietę cudzołożną, która miała być ukamienowana (J 8, 1-11), czy w końcu Piotra, który się zaparł Jezusa (J 21, 1-19). Misję Jezusa wobec grzeszników ilustrują także przypowieści o zaginionej owcy (Łk 15, 1-7), zagubionej drachmie (Łk 15, 8-10) czy przypowieść o synu marnotrawnym (Łk 15, 11-32) ${ }^{39}$.

Rzeczywistość grzechu ukazują następujące lektury z Nowego Testamentu: Rz 3, 22-26; Rz 5, 6-11; Rz 6, 16-23; Rz 7, 14-25; Rz 13, 8-14; Ef 2, 1-10; 1P 1, 13-23; 1J 1, 5-10; 2, 1-2; 1 J 2, 3-11; Ap 3, 14-22. Ewangelie: Mt 9, 1-8; Mt 9, 9-13; Mt 26, 69-75; Łk 7, 36-50; Łk 18, 9-14; Łk 23, 39-43; J 8, 1-11; J 20, 19-23.

\subsection{GRZECH JAKO CZYN PRZECIW MIŁOŚCl BOGA}

W wielu tematach Nowy Testament kontynuuje i rozwija myśl Starego Testamentu. Dotyczy to także nauki o grzechu, który ukazany jest jako działanie występujące przeciw miłości Boga. Rzeczywistość tę dobrze ukazują czytania umieszczone w lekcjonarzu Obrzędów Pokuty. Analizie zostanie poddany tekst z Ewangelii świętego Łukasza (Łk 15, 11-32). Autor Ewangelii przedstawia postać marnotrawnego syna, który swoim postępowaniem występuje przeciw Bogu. Ukazana jest też postawa starszego brata, który także odwraca się od Boga.

Nowy Testament wprowadza inną perspektywę spojrzenia na grzech i ukazuje go jako przede wszystkim odejście od Bożej miłości. Prawdę tę ilustruje Jezus w przypowieści o synu marnotrawnym (Por. Łk 15, 11-32). W przypowieści, którą lepiej tytułować „przypowieścią o miłosiernym Ojcu", grzech jest odejściem od kochającego Boga Ojca. Młodszy syn opuścił rodzinny ojca i udał się w dalekie kraje. Wcześniej żądał od ojca swojej części majątku (Łk 15, 12). Zabranie majątku świadczy o tym, że młodszy syn chciał być samowystarczalny i nie była mu potrzebna

${ }^{39}$ Zob. S. Lyonnet, Grzech, s. 309-314. 
miłość Ojca. On chciał żyć na własną rękę i stać się całkowicie niezależnym. Ów młody człowiek wzgardził miłością własnego ojca i rozpoczął poszukiwanie szczęścia. Początkowo wszystko szło po jego myśli: miał przyjaciół i towarzyszy zabaw, korzystał z wszelkich przyjemności życia i doskonale się bawił. Jednak szybko zabrakło pieniędzy i młodszy syn znalazł się w nędzy i został sam. Próbował szukać jakiegoś zajęcia, ale bezskutecznie. W końcu najął się do pasania świń, ale i tam cierpiał nędze i głód. Opis syna wśród świń obrazuje jego największe upodlenie. Dla Izraelitów nie było wymowniejszego niż ten opisu ukazującego człowieka przeklętego, grzesznika, wykluczonego z cywilnej i religijnej wspólnoty, całkowicie oddalonego od Boga i swojego narodu $u^{40}$.

Grzech jest odejściem, odwróceniem się od Boga jako kochającego Ojca. Mamy tutaj do czynienia z pragnieniem życia po swojemu, według własnych planów i własnych kryteriów moralnych. W istocie jest to zwątpienie w miłość Boga jako Ojca. Szatańska pokusa, by siebie samego postawić w miejscu Boga istnieje od stworzenia człowieka. Ona okazała się straszną pułapką dla pierwszych rodziców i jest pułapką dla nas wszystkich. Odrzucenie Boga miało dać szczęście, zadowolenie, prawdziwą wolność, wielkość. Tymczasem bardzo szybko przychodzi rozczarowanie, pojawia się strach, samotność i jakaś straszna pustka ${ }^{41}$.

W tej przypowieści pojawia się także postać starszego syna, który nie potrafił pogodzić się z ojcem, który wybaczył jego bratu odejście i zmarnowanie majątku. O młodszym bracie mówi jak o kimś obcym i dalekim. Wyraża pogardę dla grzesznika, nie zwracając uwagi, że rani ojcowską miłość: „Skoro jednak wrócił ten syn twój, który roztrwonił twój majątek z nierządnicami, kazałeś zabić dla niego utuczone cielę" (Łk 15, 30). W ten sposób również starszy syn występuje przeciw miłości ojca. Przebywając w domu ojca, miał wszystko i mógł cieszyć się wszelkim dobrem, jednak nie wierzył w miłość ojca i bał się korzystać z posiadanych dóbr.

Można powiedzieć, że starszy brat również się zagubił. Wydawać by się mogło, że jest on wspaniałym wzorem dobrego syna. Jak sam zapewnia zawsze we wszystkim był dobry i posłuszny ojcu. Tkwiąc w przekonaniu, że tylko on jest dobry, wzniósł zaporę z obłudy, która

${ }^{40}$ Por. F. Gryglewicz, Ewangelia świętego Eukasza, t. III, cz. 3, Pallottinum, Poznań-Warszawa 1974, s. 263.

${ }^{41}$ Por. M. Galizzi, Dtuga droga Jezusa, Wydawnictwo Salezjańskie, Warszawa 1989, s. 93. 
nie pozwalała mu dostrzec bezwarunkowej miłości ojca, jednakowej do obu synów. W ten sposób starszy syn oddziela się swą postawą od ojca i od młodszego brata ${ }^{42}$.

Grzech jako czyn przeciw miłości Boga przedstawia także św. Paweł, którego można nazwać największym teologiem grzechu ze wszystkich pisarzy nowotestamentalnych. Z pewnością na jego spojrzenie na grzech ogromy wpływ miało wydarzenie spod Damaszku. Apostoł sam mocno doświadczył grzechu i mocy łaski Bożej, która wyzwala i przemienia człowieka. Według niego grzech to nie tylko przekroczenie nakazu prawa, ale jest on zamknięciem umysłu i serca przed Bogiem. Człowiek zamyka się przed Bogiem, gdyż chce wszystko zawdzięczać tylko sobie, a nie łasce Bożej. Taka postawa rodzi się z pychy. Apostoł narodów widzi $\mathrm{w}$ grzechu chęć zabezpieczenia sobie życia po swojemu, bez Boga i Jego zbawczych planów (zob. Rz 3, 22-26; Rz 5, 6-11; Rz 6, 16-23; Rz 7, 14-25; Rz 13, 8-14; Ef 2, 1-10) ${ }^{43}$.

Według św. Pawła w człowieku toczy się tajemnicza i nieustanna walka (zob. Rz 7, 14-25). Z jednej strony człowieka pociąga zło, a z drugiej jego serce nieustannie tęskni za Bogiem. Paweł w swoich listach wylicza całe katalogi grzechów. Tylko Chrystus może wyzwolić człowieka z niewoli i władzy grzechu. Żyjąc w łączności i jedności z Chrystusem człowiek staje się nowym stworzeniem ${ }^{44}$. Wyzwolenie $\mathrm{z}$ niewoli grzechu dokonuje się dzięki śmierci i zmartwychwstaniu Chrystusa. On wziął na siebie grzechy wszystkich ludzi: „Dla nas uczynił grzechem Tego, który nie znał grzechu, abyśmy stali się w Nim sprawiedliwością Bożą" (2 Kor 5, 21). Boża sprawiedliwość rodzi się w człowieku poprzez doświadczenie, iż grzech jest prawdziwym złem. Według Pawła grzech jest odrzuceniem dobra, a konkretnie Bożej miłości: „Albowiem w Chrystusie Bóg jednał z sobą świat, nie poczytując ludziom ich grzechów" (2 Kor 5, 20). Tak wielkiej przemiany może dokonać tylko Bóg ${ }^{45}$.

Bóg obdarza człowieka miłością nawet wtedy, gdy ten grzeszy. Człowiek, doświadczając bezinteresownej i darmowej miłości Boga, uświa-

${ }^{42}$ Por. S.O. Abogunrin, Ewangelia wedtug św. Łukasza, w: W. R. Farmer (red.), Międzynarodowy komentarz do Pisma Świętego, s. 1282.

${ }^{43}$ Por. M. Czajkowski, Stowo Boże w odnowionych Obrzędach pokuty, w: A. Skowronek, St. Czerwik, M. Czajkowski (red.), Sakrament pokuty. Teologia. Liturgia. Pismo św., Księgarnia św. Jacka, Katowice 1980, s. 216-218.

${ }^{44}$ Por. E. Dąbrowski, Listy do Koryntian. Wstęp - przektad z oryginatu, komentarz, t. VII, Pallottinum, Poznań 1965, s. 429.

${ }^{45}$ Tamże. 
damia sobie, że przez grzech odrzuca nie prawo, lecz miłość. Trzeba także dodać, że uwolnienie z grzechu dokonuje się nie dzięki bezbłędnemu przestrzeganiu przepisów Prawa, lecz dzięki całkowitemu oddaniu się Bogu w Jezusie Chrystusie ${ }^{46}$.

\subsection{GRZECH JAKO SZANSA NA POJEDNANIE}

Grzech oddala człowieka od Boga, ale nie przekreśla możliwości powrotu. Przypowieść o synu marnotrawnym jednoznacznie pokazuje, że zawsze istnieje szansa na pojednanie i powrót do Ojca. Bóg zawsze czeka na powrót człowieka i pragnie obdarzyć go darem przebaczenia. Zarówno Stary, jak i Nowy Testament ukazują rolę grzechu w historii zbawienia. Nie jest ona pozytywna, niemniej jednak stanowi tło do ukazania miłości i mocy Boga, który potrafi zło przemienić w dobro.

Nowy Testament ukazuje grzech jako odejście i odrzucenie miłości Boga objawionej w Jezusie Chrystusie. Człowiek rezygnuje z daru bycia kochanym i kochania. Jest to dramat wolności człowieka, który niejednokrotnie gubi się na drodze ku Bogu. Chrystus, prawdziwy Bóg i prawdziwy Człowiek, przychodzi na świat po to, aby ukazać ludziom prawdziwe oblicze miłości. Prawdę tę ilustruje opowiadanie Jezusa o modlącym się faryzeuszu i celniku (Łk 18, 9-14) ${ }^{47}$.

Faryzeusz nie miał trudności w zachowaniu Bożych przykazań, cieszył się i dziękował Bogu, że w porównaniu z innymi ludźmi nie ma sobie nic do zarzucenia: „Boże, dziękuję $\mathrm{Ci}$, że nie jestem jak inni ludzie, zdziercy, oszuści, cudzołożnicy, albo jak ten celnik. Poszczę dwa razy w tygodniu, daję dziesięcinę ze wszystkiego, co nabywam” (Łk 18, 12). W modlitwie faryzeusza trudno nie zauważyć zachwytu dla swojej osoby i pochwały własnego postępowania. Zapatrzony we własną doskonałość, bardzo łatwo osądza innych ludzi. Faryzeusz spełniając drobiazgowo wymogi Prawa, wpadł w pychę, gdyż uważał, że sprawiedliwość i doskonałość osiągnął dzięki własnym wysiłkom. To powodowało, że czuł się lepszym od innych. Jego modlitwa, choć jest kierowana do Boga, to w swej istocie koncentruje się na nim samym i jego zasługach ${ }^{48}$.

${ }^{46}$ Tamże, s. 218.

47 OP 187.

${ }^{48}$ Por. S. O. Abogunrin, Ewangelia wedtug św. Łukasza, s. 1285; F. Gryglewicz, Ewangelia świętego Łukasza, s. 282. 
Natomiast celnik nie śmiał nawet oczu wznieść ku niebu, lecz bił się w piersi i mówił: „Boże, miej litość dla mnie grzesznika” (Łk 18, 13). Spuszczone oczy wyrażały pokorę i żal za popełnione winy. Miał on świadomość, że Bóg patrzy na niego i go słucha. Bił się w piersi i powtarzał prośbę o miłosierdzie mając świadomość swojej grzeszności. Bóg wysłuchał próśb grzesznika, a faryzeusz pozostał w mocy grzechu. Postawa celnika jest słuszna, gdyż on nie porównuje się $\mathrm{z}$ innymi ludźmi i nie szuka usprawiedliwienia. Stwierdza jednoznacznie, że jest grzesznikiem. Pokornie prosi o litość i zostaje wysłuchany. Świadomość popełnionych grzechów oraz ich wyznanie przed Bogiem doprowadziło go do pojednania(Łk 18, 14) ${ }^{49}$.

Świadomość popełnionych grzechów staje się zaczątkiem prawdziwego spotkania z Bogiem. Człowiek pogrążony w grzechu dostrzega nagle, że to, co czynił jest złe i pragnie się z tego wycofać. Przykładem może być postawa jednego ze złoczyńców ukrzyżowanych razem z Jezusem. Lekcjonarz Obrzędów Pokuty zawiera czytanie ukazujące scenę nawrócenia dobrego łotra (Łk 23, 39-43) $)^{50}$.

Jeden z łotrów, przypominając mesjański tytuł Jezusa, nawoływał, aby Jezus ratował ich wszystkich. Gdy jednak stracił nadzieję, jego słowa stają się bluźnierstwem: „Czy Ty nie jesteś Mesjaszem? Wybaw więc siebie i nas" (Łk 23, 39). Ten człowiek nie był w błędzie, twierdząc, ze przyjście Jezusa pociągało za sobą wyzwolenie i zbawienie. Jego błąd polegał na niezrozumieniu sposobu, $w$ jaki to zbawienie miało się urzeczywistnić. Pozostanie Jezusa na krzyżu było gwarancją wybawienia nawet najgorszego złoczyńcy ${ }^{51}$.

W obronie Jezusa stanął drugi ukrzyżowany złoczyńca. Uświadomił sobie, że ponad ludzkim sądem jest sąd Boga. Mimo, że ponoszą karę, to wyrok Boży nie został wydany i dlatego nie można bluźnić, gdyż $\mathrm{w}$ ten sposób grzeszy się jeszcze bardziej ${ }^{52}$. Dobry łotr był przekonany o swojej winie: „My przecież sprawiedliwie, odbieramy bowiem słuszną karę za nasze uczynki, ale On nic złego nie uczynił" (Łk 23, 41). W tym stwierdzeniu widzimy wiarę, że Jezus będzie mógł wstawić się za nim u Boga. Ufa, że to wstawiennictwo będzie skuteczne: „Jezu wspomnij

${ }^{49}$ Por. M. Galizzi, Dtuga droga Jezusa, s. 123; zob. F. Gryglewicz, Ewangelia świętego Łukasza, s. 282.

${ }^{50}$ OP 189.

${ }^{51}$ Por. S. O. Abogunrin, Ewangelia wedtug św. Eukasza, s. 1299.

${ }^{52}$ Por. F. Gryglewicz, Ewangelia świętego Łukasza, s. 349. 
na mnie, gdy przyjdziesz do swego królestwa" (Łk 23, 42). Jezus odpowiada na wiarę i skruchę łotra:,, Zaprawdę, powiadam ci: Dziś ze mną będziesz w raju" (Łk 23, 43). Wiara i nadzieja w Bożą miłość zrodziły się z głębokiego pragnienia przemiany. Grzech paradoksalnie przybliżył tego człowieka do Boga. On przyjął Jezusa jako swojego Zbawiciela ${ }^{53}$.

\section{ZAKOŃCZENIE}

Słowo Boże głoszone podczas liturgii pokutnej objawia prawdę. Najpierw jest to prawda o człowieku i jego słabości. Tylko w świetle i prawdzie słowa Bożego człowiek jest zdolny zobaczyć i nazwać po imieniu swój grzech. Słowo Boże ukazuje także konsekwencję grzechu. Z drugiej strony słowo Boże przynosi dobrą nowinę o Bogu, który kocha, poszukuje człowieka, odpuszcza mu grzechy i przebacza. Słowo to $\mathrm{w}$ pełni objawia nam tajemnicę zbawienia.

Słowo Boże proklamowane w czasie liturgii sakramentu pokuty i pojednania jest przede wszystkim łaską, gdyż ze słuchania tegoż słowa rodzi się wiara, która stanowi nieodzowny warunek właściwego przeżycia sakramentu pokuty i pojednania. Wiara prowadzi człowieka do prawdziwego nawrócenia. Słowa dobrej nowiny towarzyszą penitentowi w powrocie do pełnej jedności z Bogiem oraz z Kościołem.

Głoszone $\mathrm{w}$ czasie liturgii sakramentu pokuty i pojednania słowo Boże pełni funkcję katechezy mistagogicznej. Z jednej strony ukazuje rzeczywistość grzechu i jego konsekwencje, a z drugiej strony mówi o przebaczeniu i pojednaniu. Poprzez słuchanie słowa Bożego dokonuje się proces ewangelizacji sumienia. Dobra nowina, którą słyszy penitent $\mathrm{w}$ liturgii sakramentu pokuty i pojednania prowadzi go do nawrócenia, czyli do powrotu do domu Ojca.

Mając do wyboru 108 fragmentów Pisma świętego, które mogą być czytane w liturgii pojednania wielu penitentów z indywidualną spowiedzią i rozgrzeszeniem, na pewno można pogłębić przeżycie indywidualnej spowiedzi i uczynić ją drogą prowadzącą do nawrócenia.

${ }^{53}$ Por. M. Galizzi, Jezus ofiara władzy, Wydawnictwo Salezjańskie, Warszawa 1988, s. $102-103$. 


\section{LA REALTÀ DEL PECCATO NELLE LETTURE BIBLICHE DEL RITO DELLA PENITENZA}

\section{SOMMARIO}

L'articolo intitolato "La realtà del peccato nelle letture bibliche del Rito della Penitenza" propone il tema della biblica comprensione del peccato e delle sue conseguenze. Sulla base delle letture selezionate dall' Antico Testamento, il peccato è presentato come disperazione, rifiuto dell'amore paterno di Dio e disobbedienza alla sua parola. L'uomo in pratica dall'inizio della sua esistenza ha cercato di ottenere l'indipendenza dal suo Creatore. Il peccato, di cui l'essenza consiste nel dubitare nell'amore paterno di Dio, gli fece perdere l'amicizia con Dio e il dono dell'immortalità, che lo rendeva simile al suo Creatore. Il peccato è una realtà, che demolisce l'uomo nel suo interno: distrugge la sua struttura interiore corrodendo la confidenza verso se stesso, verso l'altro uomo e verso Dio. Nel Nuovo Testamento il peccato viene presentato come un atto contro l'amore di Dio, ma anche come un'occasione di riconciliazione. La buona novella annunziata da Gesů porta una profonda consapevolezza dell'esperienza del peccato. Nell'incontro con Gesů e con la sua parola l'uomo riconosce chiaramente il proprio peccato. La coscienza del peccato, perň, non distrugge l'uomo, al contrario, lo conduce verso la conversione. La missione salvifica di Gesů nella sua totalitŕ è indirizzata verso i peccatori. La ricchezza delle 108 letture bibliche inserite nel Rito della Penitenza consente una profonda esperienza della confessione individuale e conduce in questo modo alla conversione. 